\title{
Effect of hydrosorption polymers on the properties of water-swellable rubber
}

\author{
(C) Konstantin V. Efimov, Evgeny N. Egorov, Nikolay F. Ushmarin, and Nikolay I. Koltsov* ${ }^{+}$ \\ Department of Physical Chemistry and Macromolecular Compounds. Chuvash State University \\ of I.N. Ulyanov. Moskovsky Ave., 15. Cheboksary, 428015. Chuvash Republic. Russia. \\ Phone:+7 (8352) 45-24-68.E-mail: koltsovni@mail.ru
}

\begin{abstract}
*Supervising author; ${ }^{+}$Corresponding author
Keywords: caoutchoics, rubber mixture, water-swellable rubber, rheological and elastic-deformation properties, polymer hydrosorption additives, degree of volumetric swelling.
\end{abstract}

\section{Abstract}

Currently, in the oil and gas industry there is a growing demand for sealing elements capable of limited swelling upon contact with water and sealing the annular space of certain sections of the well. The swelling capacity of the sealing elements is predetermined by a well-chosen combination of polymer base and targeted functional ingredients. At the moment, a big drawback of water-swellable sealing elements is the loss of their sealing ability due to the washing out of hydrosorption additives from the sealing element. In this regard, in this work, the effect of hydrosorption polymers (polyacrylamide, sodium carboxymethylcellulose, polyvinyl alcohol and guar gum) on the properties of water-swellable rubber based on a combination of nitrile-butadiene SKN 1855, acrylate nipol AR22 and chloroprene CR 232 rubbers and epoxy 20 with sulfur curing system. The rubber mixture was prepared by mixing rubbers with ingredients on a laboratory roll LB 320 160/160. The rheological characteristics of the rubber compound were studied on an MDR 3000 Basic rheometer at $150{ }^{\circ} \mathrm{C}$. Standard rubber samples were vulcanized at $150{ }^{\circ} \mathrm{C}$ for $30 \mathrm{~min}$ in a P-V-100-3RT-2-PCD vulcanization press. The main properties of vulcanizates were determined according to the standards in force in the rubber industry. It is shown that the introduction of polyacrylamide together with sodium carboxymethyl cellulose, polyvinyl alcohol and guar gum into a rubber compound leads to a change in its rheological parameters. Vulcanizates containing a combination of polymers are characterized by lower values of the conventional tensile strength and rebound elasticity, but higher elongation at break and the degree of swelling in distilled and formation water as compared to the vulcanizate of the base version of the rubber mixture.

\section{References}

[1] O.Yu. Minol-Rakhalskaya. An innovative project by Kraiburg and NG Technology "swellable packers". New developments of elastomers in the oil and gas industry. Drilling and oil. 2017. No.5. P.46-49. (russian)

[2] E.N. Egorov, N.F. Ushmarin, S.I. Sandalov, I.S. Spiridonov, and N.I. Koltsov. The influence of functional ingredients on the physico-mechanical and operational properties of rubbers for water-oilswelling sealing elements. Butlerov Communications. 2019. Vol.57. No.2. P.68-73. DOI: 10.37952/ROIjbc-01/19-57-2-68

[3] E.N. Egorov, N.F. Ushmarin, K.V. Efimov, S.I. Sandalov, I.S. Spiridonov, and N.I. Koltsov. The influence of functional ingredients on the physico-mechanical and operational properties of rubbers for water-swelling sealing elements. Butlerov Communications. 2019. Vol.58. No.6. P.152-157. DOI: 10.37952/ROI-jbc-01/19-58-6-152

[4] N.F. Ushmarin, D.V. Pelipenko, S.I. Sandalov, E.N. Egorov, N.I. Kol'tsov. Development of rubber for water-oil-swellable packers. VII All-Russian conference "Rubber and rubber - 2017: traditions and innovations". Moscow, April 25-26, 2017. Materials of reports. Moscow. 2017. P.56-57. (russian)

[5] A.V. Ivanova, E.N. Egorov, N.F. Ushmarin, S.I. Sandalov, N.I. Kol'tsov. An investigation of the effect of methyl cellulose and sodium polyacrylate on the hydrosorption properties of a vulcanisate based on chloroprene rubber. International Polymer Science and Technology. 2018. Vol.45. No.7. P.311-314.

[6] K.V. Efimov, N.F. Ushmarin, N.I. Kol'tsov. Investigation of the properties of water-swellable rubber based on rubber combinations. XIV International Young. scientific. conf. by natural scientific. and tech. disciplines. Yoshkar-Ola, April 19-20, 2019. Collection of materials. Yoshkar-Ola. 2019. Part 3. P.36-38. (russian) 